\begin{tabular}{|} 
Ambiente \& Água - An Interdisciplinary Journal of Applied Science \\
ISSN 1980-993X - doi:10.4136/1980-993X \\
www.ambi-agua.net \\
E-mail: ambi.agua@gmail.com
\end{tabular}

\title{
Determination of gill-net selectivity for King Fish (Scomberomorus Commerson, Lacepede 1800) using Mesh size in Sungailiat, Bangka Belitung Province
}

\author{
ARTICLES doi:10.4136/ambi-agua.2721
}

Received: 09 Mar. 2021; Accepted: 21 Jun. 2021

\author{
Pareng Rengi ${ }^{1 *}$; Polaris Nasution ${ }^{2}$; Arthur Brown ${ }^{3}$; \\ Ayu Nita Ervina Tambunan 1 (D)
${ }^{\mathbf{1}}$ Faculty of Fisheries and Marine Affairs. Universitas Riau, Kampus Bina Widya, Km 12,5, 28293, Kota Pekanbaru, Riau, Indonesia. E-mail: ayu.nita5767@student.unri.ac.id
${ }^{2}$ Fisheries Resources Utilization. Universitas Riau, Kampus Bina Widya, Km 12,5, 28293, Kota
Pekanbaru, Riau, Indonesia. E-mail: polarisb2000@yahoo.com Riau, Indonesia. E-mail: arthur_psp@yahoo.co.id
*Corresponding author. E-mail: pareng.rengi@lecturer.unri.ac.id \\ ${ }^{3}$ Fish Utilization Department. Universitas Riau, jl.dharma bakti GG bambu, n 3, 28292, Kota Pekanbaru,
}

\begin{abstract}
Selectivity is a fishing gear characteristic capable of catching fish of a specific size and species from the existing population distribution. Mesh size is one of the important factors that influence gillnets' selectivity, because different length-classes of fish are caught by them. This report focuses on the selectivity of two mesh sizes of gillnets $(8.89 \mathrm{~cm}$ and $10.16 \mathrm{~cm})$ on mackerel's catch and constructing a gillnet in Sungailiat waters. Experimental fishing methods and selectivity analysis were used for the fishing gear's more selective preparation, if the largest fishing ratio's value at the fork length $(\mathrm{L})$ is high and the standard deviation value $(\mathrm{S})$ is closer to 1 . It is concluded that to be more selective a largest $S(L)$ value of 0.999267194 at fork length $(\mathrm{L}=54.95 \mathrm{~cm})$, and with a larger value of $\mathrm{S}(\mathrm{L}) 0.997096071$ and with $(\mathrm{L}=66.55 \mathrm{~cm})$ for mesh Sizes $8.89 \mathrm{~cm}$ and $10.16 \mathrm{~cm}$, respectively.
\end{abstract}

Keywords: drift gillnet, fork length, scomberomorus commerson, selectivity, sungailiat.

\section{Determinação da seletividade da rede de emalhar para King Fish (Scomberomorus Commerson, Lacepede 1800) usando o tamanho da malha em Sungailiat, província de Bangka Belitung}

\section{RESUMO}

A seletividade é uma característica das artes de pesca capazes de capturar peixes de determinado tamanho e espécie da distribuição populacional existente. O tamanho da malha é um dos fatores importantes que influenciam a seletividade da rede de emalhar. Devido ao tamanho diferente, eles pegam vários tipos de peixes. Este trabalho centra-se na seletividade de dois tamanhos de malha de emalhar $(8,89$ e $10,16 \mathrm{~cm})$ na captura de cavala e na construção de uma rede de emalhar nas águas de Sungailiat. O método de pesca experimental e a análise de seletividade foram usados para a preparação mais seletiva das artes de pesca, se o valor da maior razão de pesca para o comprimento do garfo (L) for alto e o valor do desvio padrão (S) for mais 
próximo de 1. Conclui-se que para ser mais seletivo dev ter um maior valor S (L) de 0,999267194 no comprimento do garfo $(\mathrm{L}=54,95 \mathrm{~cm})$, um maior valor $\mathrm{S}(\mathrm{L})$ 0,997096071 e com $(\mathrm{L}=66,55 \mathrm{~cm})$ para o tamanho da malha $8,89 \mathrm{~cm}$ e $10,16 \mathrm{~cm}$ respectivamente.

Palavras-chave: comprimento do grampo, rede de emalhar de deriva, scomberomorus commerson, seletividade, sungailiat.

\section{INTRODUCTION}

Fisheries play an important role in poverty alleviation, food security, nutrition supply, income, and in general to the community's socio-economic development (Mehanna et al., 2021b). Good fishery management requires proper fishing equipment to catch large adult fish and allow small fish to escape, and at least $50 \%$ of individuals would have an opportunity to reproduce (Armstrong et al., 1990). Also, fishing techniques and equipment impact biomass and crops, ecological interactions between species, and productivity and ecosystem functions that can be felt directly or indirectly (Millar and Fryer, 1999; Hall, 1996; Mehanna et al., 2021a; 2021b; Aabeed 2020).

In practice, the selection of fish catches depends on the fish's size rather than age. This is because the fish's size determines the possibility of escaping through the eyes of the net or away from the fishing gear (Mehanna et al., 2021b). Selectivity is the fishing gear's nature that catches fish of a specific size and population distribution species (Lagler, 1978). This property mainly depends on the principle used in the capture and the design parameters of fishing equipment, such as mesh size of nets, materials and thread sizes, hanging ratio, and attractive speed (Tambunan and Agustriani, 2010). In many selectivity studies on fishing, catch rates are much higher for small fishing rods than large fishing rods (Erzini et al., 1996; 1998; 1999; Halliday, 2002). Mehanna et al. (2021a) showed that large fishing rods are less efficient at catching small fish and eels but more efficient at catching larger ones. Thus the catch rate, the selectivity of size, and death of fish are influenced by the size and design of the fishing rod (Forster, 1973; Anon, 1983; Skeide et al., 1986; Bjordal and Løkkeborg, 1996)

Although continuously exploited, aquatic organisms' lives still need to pay attention to long-term sustainability, as evidenced by environmentally friendly fishing gear. Drift gillnet is a fishing tool that has environmentally friendly and selective properties. It does not endanger fishermen in taking fish, the catch is suitable for consumption, relatively safe because it only causes minor injuries to the catch, and is safe for marine habitats (Lisna et al., 2018). Selective nature means catching fish at a specific size, and having gone through mature gonads the first time. Gillnet drift selectivity determines the difference in the number of species and biomass captured by various gillnets of various sizes (Adeosun et al., 2011; Ago et al., 2014). Therefore, it is essential to know the nature and selectivity of fishing gear (Anggreini et al., 2017).

One of the fish caught on gillnet drift fishing equipment is mackerel (Scomberomorus commerson). This fish is a coastal pelagic species that often migrates in groups (Mundy and Randall, 1996), generally living at a depth between $10-70 \mathrm{~m}$ by preying on small fish and can reach $2.4 \mathrm{~m}$ in length (Froese and Pauly, 2008). The narrow-barred Spanish mackerel is a mackerel spread throughout the Indo-Pacific from the Red Sea to South Africa and Southeast Asia. It is also found to the north in China and Japan, south to Australia, and has migrated through the Suez Canal to the Levant Sea (Golani et al., 2002; Rizkalla and Heneish, 2019).

Sungailiat fishing community in Bangka Belitung Province uses gillnet drift to catch mackerel with mesh size drift gillnet used measuring $8.89 \mathrm{~cm}$ and $10.16 \mathrm{~cm}$. According to Rengi (2002), One of the factors that affect the gillnet's selectivity is the net's mesh size. Mesh sizes of different nets will also affect the number of fish caught.

Drift gillnet specifications used by fishermen in Sungailiat waters have differences with

Rev. Ambient. Água vol. 16 n. 4, e2721 - Taubaté 2021 
gillnet drift in other areas. The difference lies in webbing with multifilament choices that are not spun. The available choices result when the net is in the water and enlarges the fish caught in the net. Another difference lies in the type of material webbing made of dark blue nylon multifilament. In contrast, drift gillnet in the waters of Sungailiat is made of transparent multi monofilament nylon with ballast used as part of the net's body. Nets typically weigh more than seawater, resulting in the net sinking below the water's surface.

Based on the Code of Conduct for Responsible Fisheries (CCRF) regarding responsible fishing behavior to maintain fish sustainability, it is necessary to look at the level of selectivity and safety in fishing gear. This study therefore assessed drift gillnet selectivity with mesh sizes of $8.89 \mathrm{~cm}$ and $10.16 \mathrm{~cm}$ on the catch of mackerel and explored the construction specifications of the gillnet drift fishing equipment used.

\section{MATERIALS AND METHODS}

Selectivity of Drift Gillnet Mesh Size $8.89 \mathrm{~cm}$ and $10.16 \mathrm{~cm}$ was evaluated by using the data retrieval method on conducting live experiments on fish caught by gillnet drift fishing in the waters of Sungailiat, Bangka Belitung Province.

\subsection{Data Collection}

The data used was data on fish's body size that used data analysis and size data in two fishing tools used to construct fishing equipment. Construction measurements range from webbing measurement, rope type measurement, buoy dimension measurement, ballast, and stretcher. Then the measurement results were recorded on the construction measurement table.

This study used two types of gillnet drift fishing tools with different mesh sizes. The second capture size data of mesh size was used as data in the subsequent analysis. Measurements were made to know the hanging ratio of the capture tool by using the formula (Equation 1):

$$
E=\frac{L}{L o}
$$

$$
\begin{aligned}
& \text { Note: } \\
& \mathrm{E}=\text { Hanging ratio } \\
& \mathrm{L}=\text { Length of rope ris } \\
& \text { Lo = Length of stretched nets }
\end{aligned}
$$

\subsection{Data Analysis}

The data was analyzed using a fishing gear selectivity test against gillnet drift fishing equipment using data fork length mackerel. Then specified class range and class frequency were determined using the following formula (Walpole, 1995) (Equation 2):

$$
K=1+3.3 \log n I=1 R / K
$$

Note:

$$
\begin{aligned}
& \mathrm{K}=\text { Total class } \\
& n=\text { Total data } \\
& \mathrm{I}=\text { Distance between classes }
\end{aligned}
$$


$\mathrm{R}=$ Max value - min value

The formula used to determine $\mathrm{S}_{\mathrm{L}}$ 's value and make the selectivity curve was selected based on research Sparre and Venema (1998), as follows (Equation 3).

$$
S_{L}=\exp \left\{-\frac{(L-L m)^{2}}{2 \times S^{2}}\right\}
$$

Note:

$\mathrm{S}_{\mathrm{L}}=$ Chance of caught fish at a certain length $(\mathrm{cm})$ on a mesh size net

$\mathrm{L}_{\mathrm{m}}=$ Optimum length of fish caught on a mesh size net

$\mathrm{L}=$ Fork length of fish caught on a mesh size net

$\mathrm{S}=$ Standard Deviation

The selectivity curve is obtained from the SL data of each class from the two mesh size nets. According to Dewanti et al (2019), the selectivity curve only describes the chances of the fish being caught on the $\mathrm{Y}$-axis and at a specific size on the $\mathrm{X}$-axis. It is also following the research of Manoppo (1999) and Indah and Meilia (2014), which mentions that the capture tool is more selective when the $\mathrm{L}$ value is getting bigger, and the value of $\mathrm{S}$ is closer to the number 1 (one).

\section{RESULTS}

\subsection{Gillnet Drift Construction}

The structure of gillnet drift used by fishing communities in Sungailiat waters is almost the same as the construction of gill nets in general. However, it has characteristics that make its construction slightly different from gill nets in other areas, namely:

1. Yarn material used as webbing is a multi-monofilament thread that is not spun, so when the net is in the water, the thread that is not spun will open. This will increase the chances of catching the fish.

2. Ballast used on gillnet drifts in Sungailiat waters has a different construction than typical gillnet drift ballast. Ballast in the form of a net-connected at the bottom of the body of the net (webbing) of polyvinylidene chloride (PVDC) or so-called advice. Advice is used as ballast because the weight of the type of advice is $1.7 \mathrm{gr} / \mathrm{cm} 3$ while the bodyweight of the net (multi monofilament) is $1.14 \mathrm{gr} / \mathrm{cm} 3$ (Ardidja, 2010).

Figures 1 and 2 show drift gillnet construction, in sizes $8.89 \mathrm{~cm}$ and $10.16 \mathrm{~cm}$.

\subsection{Nets (Webbing)}

Rectangular-shaped nets with mesh nets (mesh size), namely $3.5 \mathrm{~cm}$ and $10.16 \mathrm{~cm}$ Drift GillnetSpecification, can be seen in Table 1 below. 
$1000 \mathrm{~m} \varnothing 1 \mathrm{~cm}$

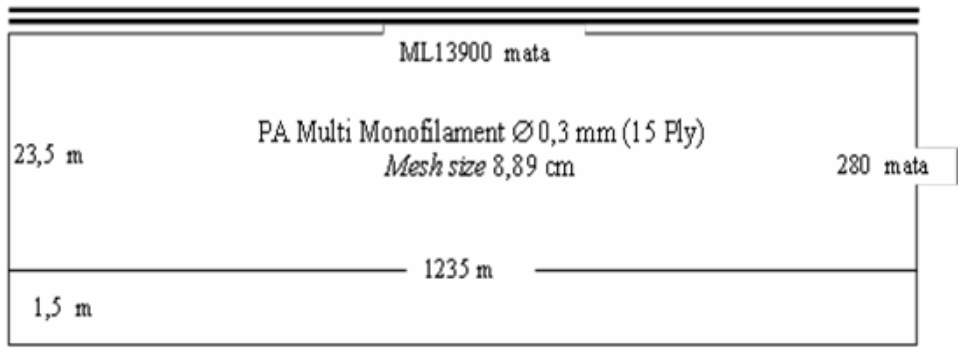

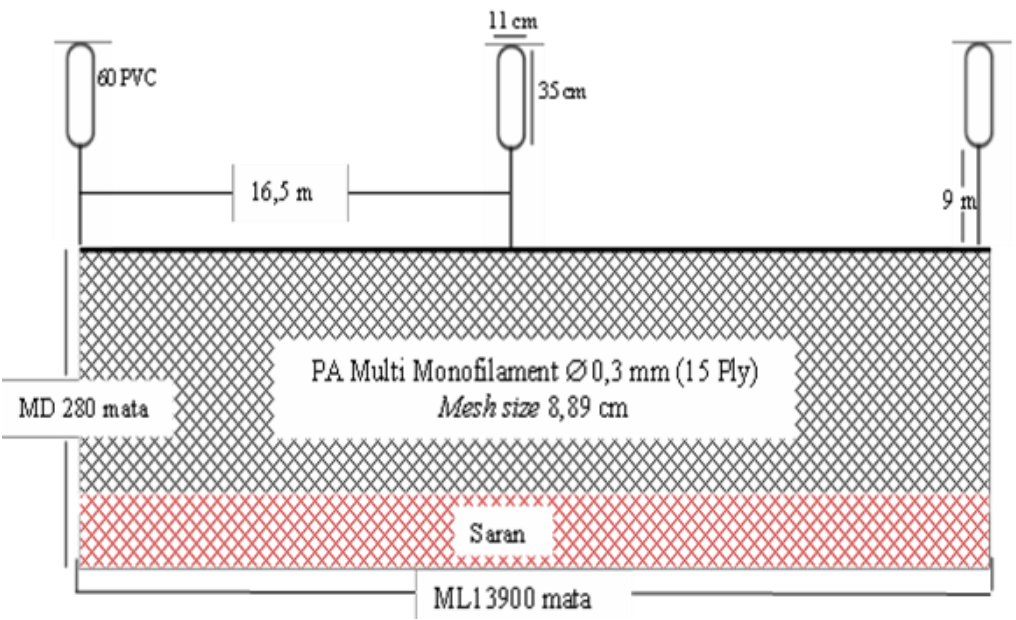

Figure 1. Gillnet drift construction with mesh size $8.89 \mathrm{~cm}$.

$1250 \mathrm{~m} \varnothing 1 \mathrm{~cm}$

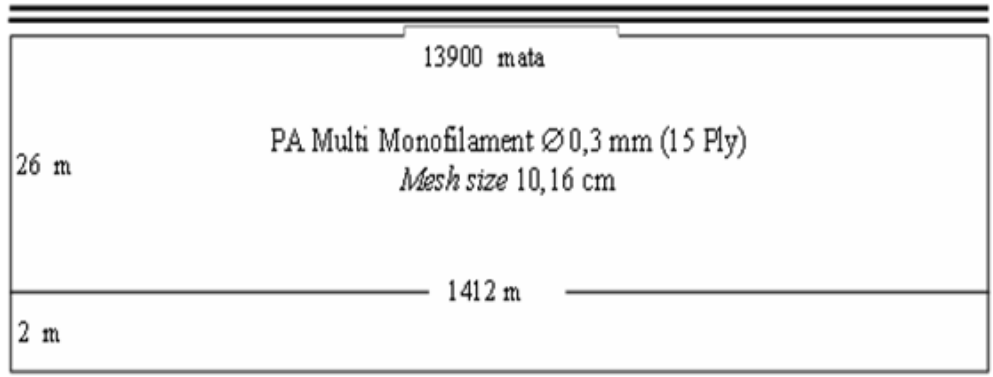

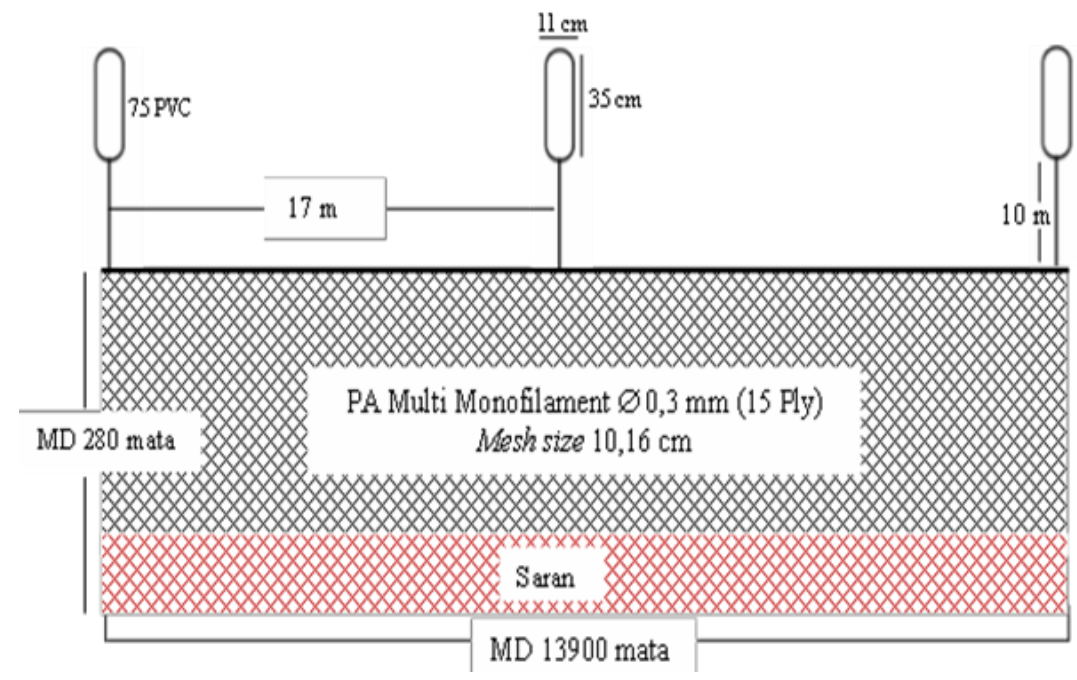

Figure 2. Gillnet drift construction with mesh size $10.16 \mathrm{~cm}$. 
Table 1. Drift Gillnet Specification.

\begin{tabular}{lcc}
\hline \multirow{2}{*}{ Net Specifications } & \multicolumn{2}{c}{ Mesh size } \\
\cline { 2 - 3 } & $\mathbf{8 , 8 9} \mathbf{~ c m}$ & $\mathbf{1 0 , 1 6} \mathbf{~ c m}$ \\
\hline Materials & PA Multi Monofilament & PA Multi Monofilament \\
Node Type & Double English & Double English \\
Thread diameter (mm) & 0.2 & 0.2 \\
Mesh length (mata) & 13900 & 13900 \\
Mesh depth (mata) & 280 & 280 \\
Hanging ratio $(\%)$ & 61 & 60 \\
Length of the strained net (m) & 1235 & 1412 \\
Net height $(\mathrm{m})$ & 25 & 28 \\
\hline
\end{tabular}

Based on Table 1, net materials use a type of Polyamide (PA) multi monofilament (15 plies) with a thread diameter of $0.20 \mathrm{~mm}$ and not spun, the length of the mesh stretched at mesh size $8.89 \mathrm{~cm}$ is $1235 \mathrm{~m}$, and at mesh size $10.16 \mathrm{~cm}$ is $1412 \mathrm{~m}$.

\subsection{Ris Rope and Life Rope}

The upper rope is a rope that connects the net to the buoy rope, while the buoy rope is a place to hang the buoy. The other function of the rope ris is to reduce and withdraw nets and protect from friction with the ship's body during the capture operation. Specifications of ris rope and buoy rope used in fishing gear can be seen in Table 2 below.

Table 2. Ris Rope and Buoy Rope Specifications.

\begin{tabular}{lcc}
\hline \multirow{2}{*}{ Ris Rope and Life Rope } & \multicolumn{2}{c}{ Mesh Size } \\
\cline { 2 - 3 } & $\mathbf{8 . 8 9} \mathbf{~ c m}$ & $\mathbf{1 0 . 1 6} \mathbf{~ c m}$ \\
\hline The length of the top ris rope (m) & 1000 & 1250 \\
Length of buoy strap (m) & 9 & 10 \\
Ris strap diameter (mm) & 10 & 10 \\
Buoy strap diameter (mm) & 10 & 10 \\
Shortcut direction & $\mathrm{S}$ & $\mathrm{S}$ \\
Materials & PE & PE \\
\hline
\end{tabular}

\subsection{Buoy}

Buoyancy serves to provide buoy on the net. Oval-shaped white PVC material (Polyvinyl Chloride) is used for buoyancy while buoys serve as a sign of the position of nets in the water. Buoy marks used are round and made of black PVC (Polyvinyl Chloride). Specifications of buoys and buoy markings can be seen in Table 3 below.

Table 3. Drift gillnet Buoy Specifications.

\begin{tabular}{lcc}
\hline \multirow{2}{*}{ Buoy Specifications } & \multicolumn{2}{c}{ Mesh Size } \\
\cline { 2 - 3 } & $\mathbf{8 . 8 9} \mathbf{~ c m}$ & $\mathbf{1 0 . 1 6}$ \\
\hline Materials & PVC & PVC \\
Forms & Oval & Oval \\
Diameter (mm) & 110 & 110 \\
Lengths (cm) & 35 & 35 \\
Quantity & 60 & 75 \\
Distance between buoys (m) & 16,5 & 27 \\
Material buoy sign & PVC & PVC \\
\hline
\end{tabular}

Rev. Ambient. Água vol. 16 n. 4, e2721 - Taubaté 2021 


\subsection{Gillnet Drift Operating Techniques}

Fishers perform the preparatory stage before going to sea, namely filling the necessary supplies such as fuel, clean water, ice, and foodstuffs. Preparation begins with checking the ship and fishing equipment, and then the ship goes to the fishing ground. The fishing ground is the water where fishers fish. The waters are believed to hold the maximum numbers of fish. The way fishers determine fishing grounds is based on fishers' experience while at sea. The fishing ground is in the Sungailiat waters of the South China Sea and can be reached by ship at a speed range of $35-50$ miles per hour navigating for 3 to 4 hours.

Upon arrival at the fishing ground, the fishers began by lowering the net into the water with a position against the water current's direction to counter the movement direction of the swimming fish. The setting process was done around 4-5 pm, as this was believed to be the best time based upon previous experience. Two fishermen lowered the net, and the setting process began when the sign buoy dropped. Then the net along with the rope was slowly lowered into the water until the net stretched perfectly. After the net was stretched, the next process was to tie the diving rope to the ship so that the net did not drift into the ship. After the setting process finished, the nets were left for 6-7 hours in the water. The last process was hauling, which takes about 2-3 hours when the hauling is done by three people, where one pulls a rope and buoys onto the boat, and another person pulls the net while taking the caught fish. The caught fish were put in a box called a "fiber" that had been filled with ice to keep the fish fresh until the ship arrived at port. Then the ship returned home to the fishing base with the catch.

\subsection{Total Catches}

The total fish caught during the study on gillnet drift fishing equipment was 369 fish with a total catch weight of $630.5 \mathrm{~kg}$. The fish caught consisted of pelagic fish of different types. The most caught fish was mackerel.

In the drift gillnet with mesh size, $8.89 \mathrm{~cm}$ caught 213 fish with a total weight of $309.1 \mathrm{~kg}$, while the mesh size of $10.16 \mathrm{~cm}$ caught 156 fish with a total weight of $321.4 \mathrm{~kg}$. The catch is shown in Figures 3 and 4 below.
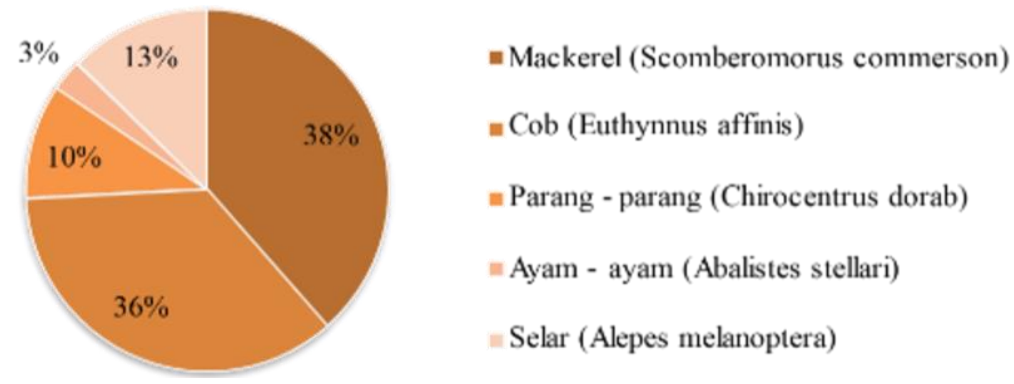

Figure 3. Fish caught on drift gillnet with a mesh size of $8.89 \mathrm{~cm}$.

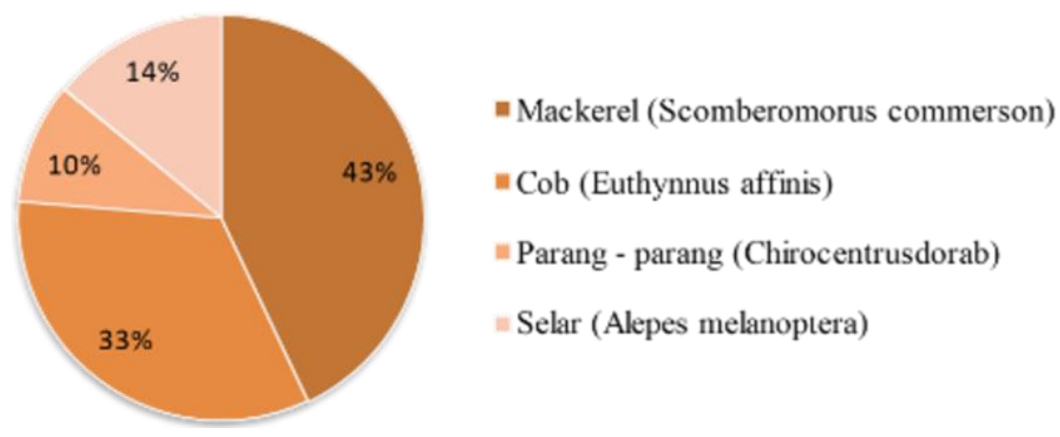

Figure 4. Fish caught on drift gillnet with a mesh size of $10.16 \mathrm{~cm}$. 
Based on Figure 3 and 4, known fish caught on drift gillnet with mesh size $8.89 \mathrm{~cm}$, namely Mackerel (Scomberomorus commerson) 38\% (Lacepede, 1800), Cob/Kawakawa (Euthynnus affinis) 36\% (Cantor, 1849), Parang-parang/Dorab wolf-herring (Chirocentrus dorab) 10\% (Forsskål, 1775), Ayam-ayam/Starry Triggerfish (Abalistes stellari) 3\% (Bloch \& Schneider, 1801), and Selar/Blackfin Scad (Alepes melanoptera) 13\% (Swainson, 1839).

In contrast, the fish caught on drift gillnet with mesh $10.16 \mathrm{~cm}$, namely Mackerel (Scomberomorus commerson) 43\% (Lacepede, 1800), Cob/Kawakawa (Euthynnus affinis) 33\% (Cantor, 1849), and Parang-parang/Dorab wolf-herring (Chirocentrus dorab) 10\% (Forsskål, 1775), and Selar/Blackfin Scad (Alepes melanoptera) 13\% (Swainson, 1839).

\subsection{Mackerel Body Measurement}

The measurement of mackerel's body (Scomberomorus commerson) is the most common catch on gillnet drift-fishing equipment. Measurement includes total length, standard length, fork length, body width, and fish-body girth. The body size range of mackerel caught with mesh sizes of $8.89 \mathrm{~cm}$ and $10.16 \mathrm{~cm}$ is shown in Table 4.

Table 4. The body-size range of mackerel (Scomberomorus commerson).

\begin{tabular}{|c|c|c|c|c|c|c|}
\hline \multirow{2}{*}{$N^{\circ}$} & \multirow{2}{*}{ Mesh Size (cm) } & \multicolumn{4}{|c|}{ Size } & \multirow{2}{*}{ Fish Weight (kg) } \\
\hline & & Total Length & Fork Length & Body Width & Body Girth & \\
\hline 1 & 8.89 & $35-90$ & $26-82$ & $8-12$ & $19-27$ & $0,8-3$ \\
\hline 2 & 10.16 & $49-115$ & $42.5-107$ & $10-14$ & $22-30$ & $1-5.3$ \\
\hline
\end{tabular}

Based on Table 4, the difference in the size of the mesh eye (mesh size) shows the difference in catches that include the difference in the size of the total length, fork length, body width, body girth, and weight of mackerel (Scomberomorus commerson). The catch with a mesh size of $10.16 \mathrm{~cm}$ catches a larger fish compared to a mesh size of $8.89 \mathrm{~cm}$. Following the opinion of Yahya and Sulaiman (2008), the larger mesh size of the net obtains a catch with a larger fish length size and vice versa. According to Takwin (2005), pelagic fish properties such as mackerel are also causing caught fish to have several size groups. However, it has not explained the degree of selectivity of the fish's body size difference. Therefore, it is necessary to take further measurements and analysis.

Long relationships and the circumference of the fish's body by conducting a regression analysis on mackerel (Scomberomorus commerson) shows how much influence on the circumference of the body of the mackerel. The results of the analysis show in the following image.

Regression analysis between the fish's length and the fish's body circumference, as shown in Figure 5, obtained the equation on the fishing tool with a mesh size of $8.89 \mathrm{~cm}$ is $\mathrm{y}=0.1085 \mathrm{x}$ +16.508 . It shows that as each mackerel length increases by $1 \mathrm{~cm}$, the average circumference of its body increases by $0.1085 \mathrm{~cm}$. The coefficient determination $(\mathrm{R})$ of $\mathrm{R}^{2}=0.5286$ indicates that the fish-length factor affects the circumference of fish by $52.86 \%$, while other factors influence the remaining $47.14 \%$. While the correlation value (r) is 0.73 , this value (r) close to 1 means that the length and circumference of the body can be a real relationship. The mesh size $10.16 \mathrm{~cm}$ obtained the equation $\mathrm{y}=0.1463 \mathrm{x}+15.702$. This shows that as each mackerel length increases by $1 \mathrm{~cm}$, the average circumference of the body increases by $0.1463 \mathrm{~cm}$. Coefficient determination $(\mathrm{R})$ of $\mathrm{R}^{2}=0.7123$ indicates that the fish length factor affects fish's circumference by $71.23 \%$, while other factors influence the remaining $28.77 \%$. While the correlation value (r) is 0.84 , this value (r) close to 1 means that the length and circumference of the body can be real or affect relationships. 

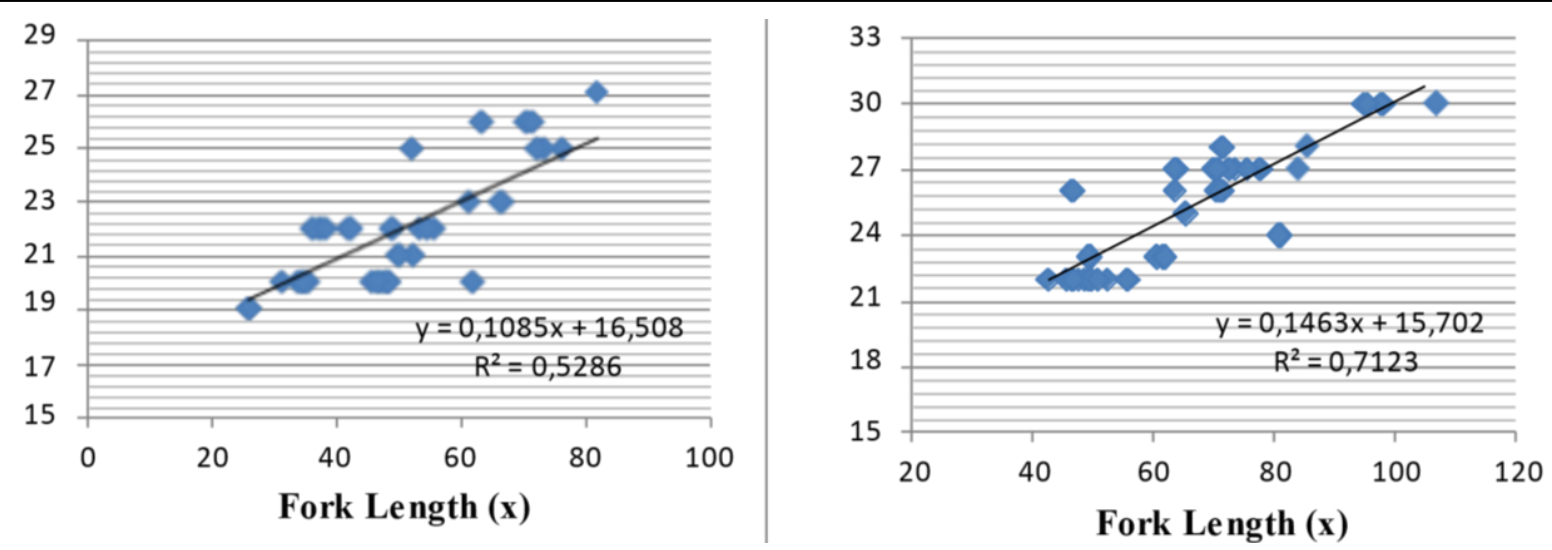

Figure 5. Fork Length and Body Girth relationship graph of mackerel caught on the difference of mesh size $8.89 \mathrm{~cm}$ and $10.16 \mathrm{~cm}$.

\subsection{Selectivity Analysis}

The calculation fork length of the most-caught fish is mackerel (Scomberomorus commerson), judging by the mackerel class's long spread. The fish-body size data used in the data analysis is fork length and then determined each class's range. The fork-length frequency distribution is shown in Table 5.

Table 5. Fork-Length Frequency Distribution.

\begin{tabular}{ccc}
\hline \multirow{2}{*}{ Class Range } & \multicolumn{2}{c}{ Mesh Size } \\
\cline { 2 - 3 } & $\mathbf{8 . 8 9} \mathbf{~ c m}$ & $\mathbf{1 0 . 1 6} \mathbf{~ c m}$ \\
\hline $26-37.5$ & 20 & 0 \\
$37.6-49.1$ & 28 & 12 \\
$49.2-60.7$ & 17 & 13 \\
$60.8-72.3$ & 12 & 25 \\
$72.4-83.9$ & 5 & 10 \\
$84-95.5$ & 0 & 4 \\
$95.6-107.1$ & 0 & 3 \\
\hline
\end{tabular}

From the table above, we estimated the value $a=-0.4942986$ and the value $b=0.00821684$ by regressing between the number of fish caught with the median value of the fish-fork length. Then we obtained the value of SF $=16.04180643$, the value of $S 2=976.1542937$, and the $1 \mathrm{~m}$ values on both mesh sizes: $56.1463225 \mathrm{~cm}$ and $64.16722571 \mathrm{~cm}$.

Then we calculated the value of S(L) using a predefined formula. The value that was obtained was used to determine the curve of the selectivity ratio. The $\mathrm{S}(\mathrm{L})$ values that were obtained are as follows (Equations 4 and 5):

$$
\begin{array}{ll}
\text { Drift Gillnet mesh size } 8.89 \mathrm{~cm} & S(L a)=\exp \left\{-\frac{(L-56,146)^{2}}{2(976,154}\right\} \\
\text { Drift Gillnet mesh size } 10.16 \mathrm{~cm} & S(L a)=\exp \left\{-\frac{(L-64,167)^{2}}{2(976,154}\right\}
\end{array}
$$

From the equations of the function obtained, a selectivity curve of mackerel fish (Scomberomorus commerson) was formed. The selectivity curve shows whether the fishing gear is selected or not by calculating the probability or chance value of catching fish with each fishing gear (Dewanti et al., 2019). The curve can be seen in Figures 6 and 7 below. 


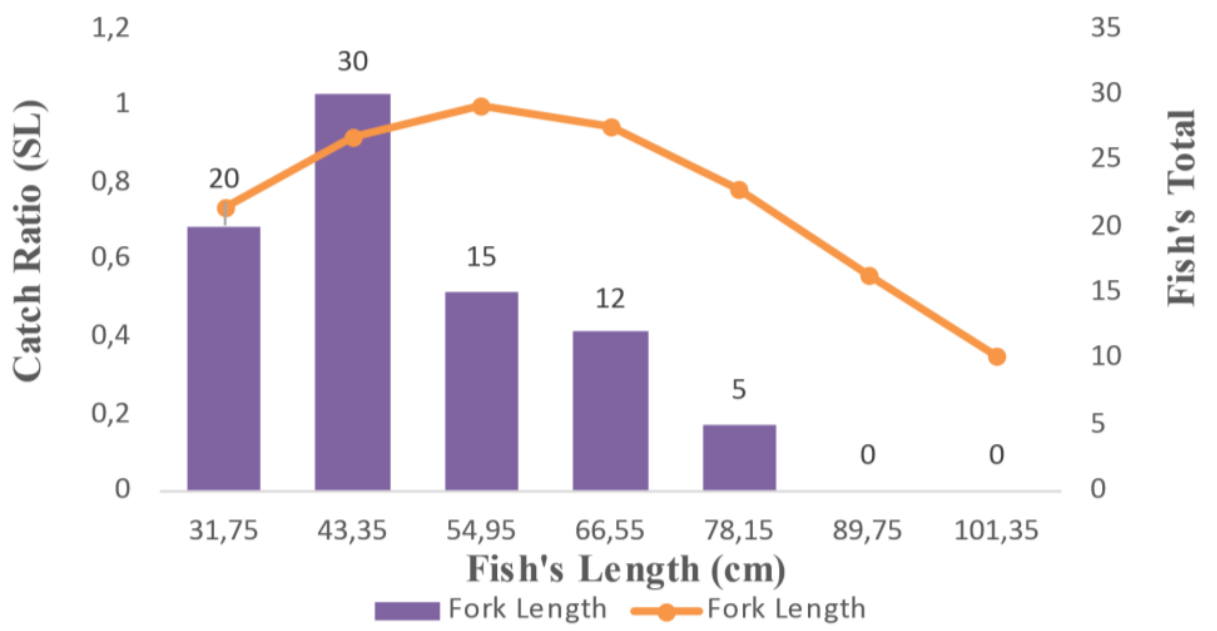

Figure 6. Selectivity chart of mackerel gillnet drift catch (Scomberomorus sp.) at a mesh size of $8.89 \mathrm{~cm}$.

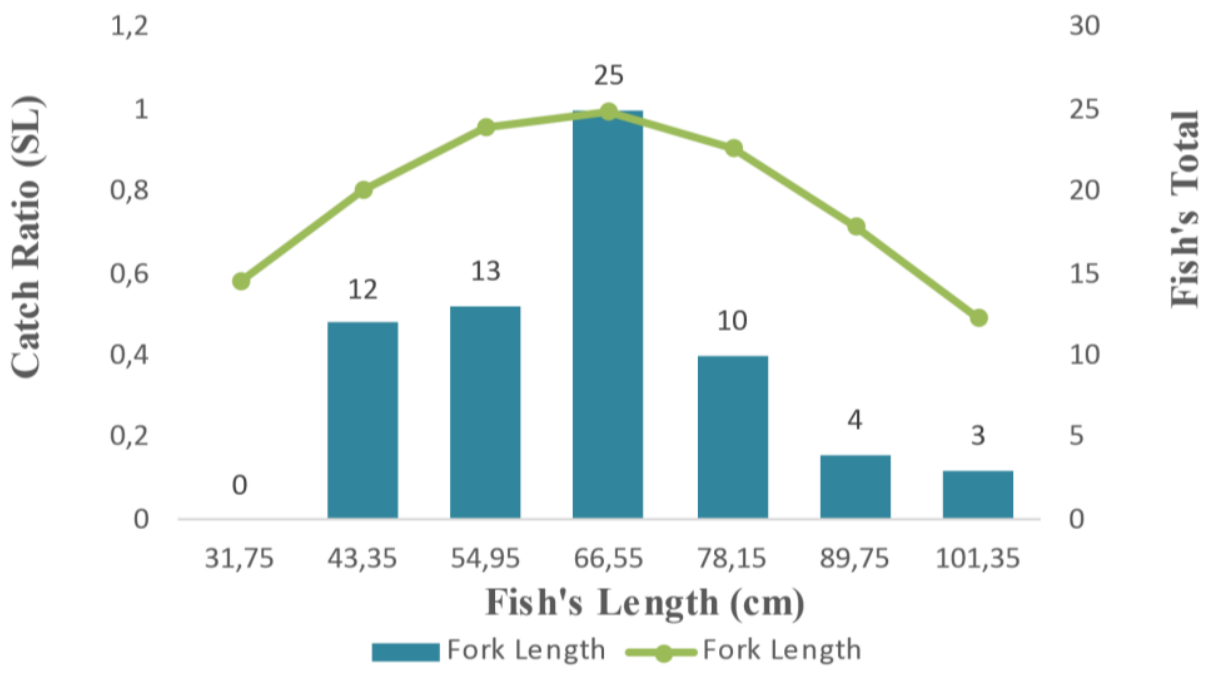

Figure 7. Selectivity chart of mackerel gillnet drift catch (Scomberomorus sp.) at a mesh size of $10.16 \mathrm{~cm}$.

In Figure 6, the largest catch ratio value for S (L) is 0.999267194 at fork length $(\mathrm{L})=54.95 \mathrm{~cm}$, totaling $15 \mathrm{fish}$. Whereas in Figure 7, the largest $\mathrm{S}(\mathrm{L})$ value is 0.997096071 at fork length $=66.55 \mathrm{~cm}$, totaling 25 fish. Based on this, the drift gillnet with a mesh size of $8.89 \mathrm{~cm}$ is more selective in catching mackerel than drift gillnet with a mesh size of $10.16 \mathrm{~cm}$. These results are following the research of Manoppo (1999) and Indah and Meilia (2014), which states that the greater the fork length $(\mathrm{L})$ and the closer the standard deviation $(\mathrm{S})$ value to 1.00 will make the selectivity value of fishing gear more selective.

\section{CONCLUSION}

The construction of drift gillnet in Sungailiat waters is different from drift gillnet generally. The net body is made of polyamide (PA) multi monofilament exact color, and the mesh sizes used are $8.89 \mathrm{~cm}$ and $10.16 \mathrm{~cm}$. The weight used in drift gillnet is part of the net's body, located under the net's body, and is commonly known as the net's foot with generally green or brown tendencies. The net legs are made of Polyvinylidene Chloride (PVDC), commonly called a "nest" with a diameter of $0.5 \mathrm{~mm}$ and about 1.5 to $2 \mathrm{~m}$.

Based on the selectivity curve, drift gillnet with a mesh size of $8.89 \mathrm{~cm}$ is more selective 
in catching mackerel with the largest $S$ (L), namely 0.999267194 and fork length $=54.95 \mathrm{~cm}$, totaling 15 fish compared to drift gillnet with mesh size $10.16 \mathrm{~cm}$ with the largest $\mathrm{S}(\mathrm{L})$, specifically 0.997096071 and fork length $=66.55 \mathrm{~cm}$, amounting to 25 fish.

\section{REFERENCES}

AABEED, M. S. Assessment of fishing gears used in Bardawil lagoon. 2020. MSc Thesis (Animal Production \& Fish resources) - Agriculture Fac., Suez Canal University, Egito, 2020.

ADEOSUN, F. I.; OMONIYI, I. T.; AKEGBEJO-SAMSONS, Y.; OLUJIMI, O. O. The fishes of the Ikere Gorge drainage system in Ikere, Oyo State, Nigeria: taxonomy and distribution. Asiatic Journal of Biotechnology Resources, v. 2, n. 04, p. 374-383, 2011.

AGO, N. D.; BINYOTUBO, T. E.; KWEN, K. Meshsize selectivity of multifilament gillnet at Fakun Village, North of Lake Jebba. Journal of Fisheries and Aquatic Science, v. 9, n. 4, p. 272-276, 2014. https://dx.doi.org/10.3923/jfas.2014.272.276

ANGGREINI, A. P.; ASTUTI, S. S.; MIFTAHUDIN, I.; NOVITA, P. I.; WIADNYA, D. G. R. Uji Selektivitas Alat Tangkap Gillnet Millenium Terhadap Hasil Tangkapan Ikan Kembung (Rastrelliger Brachysoma). Journal of Fisheries and Marine Research, v. 1, n. 1, p. 24-30, 2017. http://dx.doi.org/10.21776/ub.jfmr.2017.001.01.5

ANON, A. Circle hooks outfish traditional halibut hooks. Marine Fisheries Review, v. 45, p. 10-12, 1983.

ARDIDJA, S. Bahan Alat Penangkapan Ikan. Jakarta: STP Press Edisi 1, 2010. 189 p.

ARMSTRONG, D. W.; FERRO, R. S. T.; MACLENNAN, D. N.; REEVES, S. A. Gear Selectivity and The Conservation of Fish. Journal of Fish Biology, 37, p. 261-262, 1990. https://doi.org/10.1111/j.1095-8649.1990.tb05060.x

BJORDAL, Å.; LØKKEBORG, S. Longlining. Fishing News Books. Oxford: Osney Mead, 1996. $170 \mathrm{p}$.

DEWANTI, L. P.; SIENNA, Y. I.; KHAN, A.; APRILIANI, I. M.; HERAWATI, H. Selektivitas Gillnet Yang Menangkap Sumberdaya Ikan Layur (Trichiurus lepturus) Di Kabupaten Pangandaran. Albacore Jurnal Penelitian Perikanan Laut, v. 3, n. 3, p. 273 281, 2019. https://doi.org/10.29244/core.3.3.273-281

ERZINI, K.; GONCALVES, J. M. S.; BENTES, L.; LINO, P. G.; RIBEIRO, J. Catch composition, catch rates and size selectivity of three long-line methods in the Algarve (southern Portugal). Boletín Instituto Español de Oceanografía, v. 14, n. 1-4, p. 313323, 1999. http://hdl.handle.net/10400.1/8961

ERZINI, K.; GONCALVES, J. M. S.; BENTES, L.; LINO, P. G.; RIBEIRO, L. Species and size selectivity in a 'red' sea bream longline 'métier' in the Algarve (Southern Portugal). Aquatic Living Resource, v. 11, p. 1-11, 1998. https://doi.org/10.1016/S09907440(99)80025-4

ERZINI, K.; GONÇALVES, J. M. S.; BENTES, L.; LINO, P. G.; CRUZ, J. Species and size selectivity in a Portuguese multispecies artisanal long-ling fishery. ICES Journal of Marine Science, v. 53, n. 5, p. 811-819, 1996. https://doi.org/10.1006/jmsc.1996.0102 
FORSTER, G. R. Line fishing on the continental slope the selective effect of different hook patterns. Journal of the Marine Biological Association of the United Kingdom, v. 53, p. 749-751, 1973. https://doi.org/10.1017/S002531540002244X

FROESE, R.; PAULY, D. FishBase. World web electronic publication, 2008. Available at: https://www.fishbase.de/. Access: July 2021.

GOLANI, D.; ORSI RELINI, L.; MASSUTI, E.; QUIGNARD, J. P. CIESM Atlas of Exotic Species in the Mediterranean. Monaco: CIESM Publishers, 2002. 256 p.

HALL, M. A. On bycatches. Reviews in Fish Biology and Fisheries, v. 6, p. 319-352, 1996. https://doi.org/10.1007/BF00122585

HALLIDAY, R. G. A comparison of size selection of Atlantic cod (Gadus morhua) and haddock (Melanogrammus aeglefinus) by bottom longlines and otter trawls. Fisheries Research, v. 57, n. 1, p. 63-73, 2002. https://doi.org/10.1016/S0165-7836(01)00336-8

INDAH, N.; MEILIA, S. Statistika Deskriptif dan Induktif. Yogyakarta: Graha Ilmu, 2014. $274 \mathrm{p}$.

LAGLER, K. F. Capture, Sampling and Examination of Fish. In: BAGENAL, T. (ed.). Methods for the Assessment of Fish Production in Fresh Waters. Oxford: Blackwell Scientific, 1978. p. 7-45.

LISNA, L.; AMELIA, J. M.; NELWIDA, N.; ANDRIANI, M. Tingkat Keramah Lingkungan Alat Tangkap Gill Net di Kecamatan Nipah Panjang, Jambi. Jurnal Teknologi Perikanan dan Kelautan, v. 9, n. 1, p. 83-96, 2018. https://doi.org/10.24319/jtpk.9.8396

MANOPPO, L. Selektivitas Gill net Hanyut Terhadap Ikan Cakalang (Katsuwonus pelamis) di Perairan Lepas Pantai Selatan Jawa Barat. 1999. Dissertation - Institut Pertanian Bogor, Indonesia, 1999.

MEHANNA, S. F.; HASSANEN, G. D.; AHMED, M. S.; MOHAMED, O. A. Assessing the effect of hook style on size selectivity and catch rate of the European eel Anguilla anguilla in Bardawil Lagoon, Eastern Mediterranean, Egypt. Egyptian Journal of Aquatic Biology and Fisheries, v. 25, n. 1, p. 783-794, $2021 \mathrm{a}$. https://dx.doi.org/10.21608/ejabf.2021.150836

MEHANNA, S. F.; HASSANEN, G. D.; AHMED, M. S.; MOHAMED, O. A. The Effect Of Hook Size On Size Selectivity In Bardawil Lagoon Artisanal Longline Fishery, Eastern Mediterranean, Egypt. Egyptian Journal of Aquatic Biology and Fisheries, v. 25, n. 1, p. 511-523, 2021b. https://dx.doi.org/10.21608/ejabf.2021.145706

MILLAR, R. B.; FRYER, R. J. Estimating the size-selection curves of towed gears, traps, nets and hooks. Reviews in Fish Biology and Fisheries, v. 9, n. 1, p. 89-116, 1999. https://doi.org/10.1023/A:1008838220001

MUNDY, B. C.; RANDALL, J. E. Coastal Fishes of Oman. Honolulu: Univ. of Hawaii Press, 1996. $432 \mathrm{p}$.

RENGI, P. Pengaruh Hanging Ratio Terhadap Selektivitas Drift gillnet: Experimental Fishing Di Perairan Kab. Bengkalis, Riau. 2002. Tesis - Institut Pertanian Bogor, Indonesia, 2002. 
RIZKALLA, S. I.; HENEISH, R. A. A comparative study on the morphometric characters of the first recorded west African Spanish mackerel Scomberomorus tritor (Cuvier, 1832) and the Red Sea migrant narrow barred Spanish mackerel Scomberomorus commerson (Lacepsde, 1800) family: Scombridae i. Egyptian Journal of Aquatic Biology \& Fisheries, v. 23, n. 1, p. 217-222, 2019. https://dx.doi.org/10.21608/ejabf.2019.26686

SKEIDE, R.; BJORDAL, Å.; LØKKEBORG, S. Testing of a new hook design (E-Z Baiter) through comparative longline fishing trials. Ices, 1986.

SPARRE, P.; VENEMA, C. S. Introduction to tropical fish stock assessment. Part I: Manual. Rome: FAO, 1998. p. 1-407. (FAO Technical Paper, v. 306).

TAKWIN. Hasil tangkapan utama dan sampingan unit penangkapan Payang di Pelabuhan Ratu Sukabumi. 2005. Thesis - IPB University, 2005.

TAMBUNAN, S. B. S.; AGUSTRIANI, F. Selektivitas Drift gillnet Ikan Kembung Lelaki (Rastrelliger kanagurta) Di Perairan Belawan Pantai Timur Sumatera Utara Provinsi Sumatera Utara. Maspari Journal: Marine Science Research, v. 1, n. 1, p. 63-68, 2010. https://doi.org/10.36706/maspari.v1i1.1121

YAHYA, M.; SULAIMAN, M. Kajian Selektivitas Jaring Insang Hanyut Pada Penangkapan Ikan Terbang di Kabupaten Majene. Jurnal Teknologi Perikanan dan Kelautan, v. 14, n. 1, p. 38-43, 2008. https://doi.org/10.31227/osf.io/9c8g5

WALPOLE, R. E. Pengantar Statistik. Jakarta: Gramedia Pustaka Utama, 1995. 515 p. 